\title{
DESCRIPTIONS OF SOME NEW EXOTIC SPECIES OF STAG BEETLES (COLEOPTERA: LUCANIDÆ) ${ }^{1}$
}

\section{By BeRnaRd BENESH \\ North Chicago, Illinois}

The present paper, covering seven forms new to science, is primarily based on material conserved in our principal collections at institutions indicated hereafter. The writer's best thanks are due to Drs. Nathan Banks, R. E. Blackwelder, E. A. Chapin, E. T. Cresson, Jr., C. H. Curran, P. J. Darlington, Jr., F. E. Lutz, and J. A. G. Rehn for the opportunity of examining the Lucanidæ under their charge, and the privilege of describing the new forms discovered, as well for the many examples, so generously presented, for incorporation in the writer's collection.

Many valuable data were gained from the vast number of specimens examined and some obvious synonymies noted, which, however, are reserved for a future paper.

The new forms may be diagnosed as follows:

Calcodes (Neolucanus) maculosus (Didier) ô

Didier, Etudes sur les Coléoptères Lucanides du Globe, fasc. 7, p. 143, o, fig., 1930.

In habitus allied to $N$. laticollis (Thun.), a species endemic to Java.

o Head transverse, black, gradually diffused toward the base into chocolate-brown, opaque; mentum broad, nearly straight in front, anterior angles broadly rounded, sides elevated, base nearly straight, declivous in front, remotely punctured with fairly large, shallow punctures. Mandibles porrect, bent upward from basal half, inner edge dentate with a series of five teeth, which number may vary in larger examples. Prothorax broader than long, dark mahogany-brown, disc shining, mar-

${ }^{1}$ Published with the aid of a grant from the Museum of Comparative Zoology, Harvard College. 
ginal areas opaque, with a $\mathrm{C}$-shaped black macula in posterior corners; front margin sinuate, anterior angles obtuse, broadly rounded to posterior angle (broadest part of prothorax), thence obliquely truncate to base, latter nearly straight; a median impressed line extends from the front margin to center of the disc (this line extending the full length of the pronotum in the female). Scutellum heart-shaped, with fairly large, close punctures on the base. Elytra obovate, humeri rounded, broadest in the basal third, posterior gently rounded, with two feebly impressed lines, between the humeri and scutellum; of the same color as prothorax, but more shining, margins and suture black; a lateral, orange-yellow macula extends diagonally from humerus to within one and one-half millimeters of the suture and apex. Surface of the head, prothorax and elytra with remote punctures, those on the head largest.

Beneath slightly darker than on the dorsum, feebly shining; anterior tibiæ bifurcate at tip, and not as broad as in the female, with two strong spines in the distal half; intermediate and posterior tibiæ linearly sculptured, spineless; femora remotely punctured, each puncture bearing a short golden seta; abdominal segments margined in black, finely punctured.

Dimension: Length (excl. mandib.) $22.5 \mathrm{~mm}$; mandibles $3 \mathrm{~mm}$. Head $7.75 \mathrm{~mm}$. wide; $4.5 \mathrm{~mm}$. long (excl. mandib.) Prothorax $11.5 \mathrm{~mm}$. wide; $6.0 \mathrm{~mm}$. long (at middle) Elytra $11.25 \mathrm{~mm}$. wide; $14.25 \mathrm{~mm}$. long

Allotype: $\hat{\delta}$, Bangkinang, Sumatra, in the Museum of Comparative Zoölogy, Cambridge, Mass.

The female holotype, described by Dr. Didier, does not differ to any extent from the male; in habitus it is slightly broader, resembling much the common Javanese laticollis, to which group it phylogenically belongs. The range of the insect, unknown to Dr. Didier, is now ascertained to be Sumatra.

\section{Prismognathus branczicki Nonf., 우}

Nonfried, Berliner Entomologische Zeitschrift 50: 11, $\hat{\delta}$, 1905.

The female, hitherto undescribed, is characterized in subjoined brief diagnosis:

\& Golden brown, brassy, shining, elongate (narrower than 
the female $P$. subaëneus Motsch., used throughout in comparison). Head transverse, broader than long, with a triangular depression, deeper in the frontal angles, extending from the clypeal ridge to occiput; anteocular bosses higher and narrower. Pronotum similar in outline to subaëneus, distinctly broader than the base of elytra, with a blackish crescent-shaped macula in posterior angles. Scutellum dark. Elytra one and one-half times as long as wide, diverging to basal third, parallel in median third, thence broadly rounded, base of elytra strongly depressed in ante-humeral area, apical margin distinctly diaphanous. Dorsum uniformly punctured with fairly large, shallow punctures.

Differs from subaëneus by its slender and graceful form, finer puncturation, coloration (in subaëneus dark castaneus or entirely black), pronotal macula and translucent elytral margins, which, according to Nonfried, is typical of the species.

Allotype: ? , Szechwan, China, D. C. Graham, $1700 \mathrm{ft}$. In the United States National Museum, Washington, D. C.

\section{Prosopocoilus duplodentatus n. sp.}

Oblong, finely granulate punctate throughout, allied to $P$. rubens Didier.

$\hat{o}$ Head nearly quadrate, broader than long, black, opaque, anterad concave, sloping abruptly toward the clypeus; clypeus subtriangular, with a feeble transverse marginal ridge, top rounded; antero-lateral angles rounded, behind the eyes acuminate, the acumination extending beyond the eyes and overreaching the anterior angles of pronotum; eyes fairly large, round, shining, encompassed halfway by the lateral diagonal canthus; anteocular bosses prominent, gently sloping toward the eyes; anterad to these and slightly inward a roundish fovea. Vertex shallowly and distantly punctured by fairly large transverse-ovate punctures, becoming larger (lunate) behind the eyes. Mandibles asymmetrical, longer than the head, porrect, uniformly arcuate, laterad rounded, interior margin dentate; left mandible with a broad basal cuspidate tooth and four well defined denticles; right mandible with six denticles, the fourth (from the base) largest; below the cuspidate tooth of the left mandible and the two basal denticles of the right, is a column of three teeth on the left and a like number on the right, making 
the bases of the mandibles appear like the crown of a molar; the right mandible in repose (clinched) is uppermost and slightly shorter than the left. Antennæ: scape club-shaped, slightly bent, longer than the funicle and clava combined, black, glabrous, with a few setæ at the elbow, and when folded backward, extending to the acuminate post-ocular process; funicle one fifth longer than the clava, first segment subglobose (pearshaped), slightly longer than the second; second, third and fourth of equal length, subcylindrical, anterad dilated, fifth nearly pentagonal in outline and distinctly longer than the fourth, with a single seta on the apex, sixth as long as the fifth, produced into an elongate acute point, on which occurs a clump of setæ; clava compact, three-jointed, rufescent, eighth segment anterad produced in a lobe with a truncate apex, base glabrous, black, lobe spongy, ninth segment spongy throughout, lobe pointed, tenth segment rounded, spongy, embellished with a central circular litura; lobes of clava distinctly flattened. Prothorax broadly convex, nearly twice as broad as long, granulate punctate, opaque, disc with a few scattered punctures, feebly shining; anterior and lateral areas shallowly pitted with roundish, large pits, gradually diminishing in size and intensity toward the posterior angle; anterad bisinuate, antero-lateral angles obtusely pointed, broadly rounded from anterior third to posterior angles, latter produced into an obtuse point, thence diagonally truncate to base, which is broadly rounded; margins reflexed, laterad and basad delineated by an impressed line. Scutellum as long as broad, heart-shaped, with several irregular punctures, shining. Elytra narrower than the prothorax, broader, however, than the prothoracic base, one and one-half times as long as broad, broadest one quarter the length from humeri, parallel to the middle, thence gradually and gently rounding to apex; humeri angulate and rounded on top; each elytron with a single stria, beginning in the ante-humeral region (one-third the elytral width) and attaining to four-fifths the elytral length; margins reflexed from the broadest point to apex; dark chocolate-brown, densely punctured, opaque; suture narrowly impunctate, shining. Legs fairly stout, black, linearly sculptured; anterior tibiæ distad broadly bilobed, armed externally with four large teeth, second largest, serrate between; intermediate tibiæ with a single central spine, posterior with a denticle; tarsi as long as the tibiæ, glabrous, each 
joint furnished, on the venter, with a tuft of golden setæ at the extremity; onychium present; intermediate and posterior tibiæ sparingly clothed with short golden setæ increasing in length and density toward the extremities. Beneath deep chocolatebrown, glabrous; maxillary and labial palpi reddish; mentum feebly bilobate in front, laterad rounded, nearly as long as broad, roughly sculptured by large confluent pits; genæ similarly sculptured as the top of head behind the eyes; prosternal process prominent, terminating in an obtuse point; abdominal segments emarginate, with a few scattered punctures, shining. Length, without mandibles, $17.5 \mathrm{~mm}$; mandibles $2.75 \mathrm{~mm}$. Female unknown.

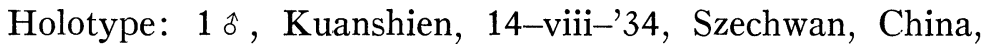
Dr. D. C. Graham, collector, in the United States National Museum, Washington, D. C.

Closely allied to the Sumatran P. rubens Didier, ${ }^{2}$ from which it can be readily separated by its dark coloration (bright mahogany red in rubens), shorter mandibles, broad pronotum (in rubens not broader than the head, laterad parallel, overlapped by the postocular spine), ovate elytra (rubens distinctly parallel) and the granulose sculpture (rubens smooth, shining).

Lissapterus montivagus n. sp. Figs. 2, 2a, 2b

Robust, convex, black, feebly shining; allied to L. tetrops Lea, and L. hopsoni Carter.

o Head transverso-quadrate, convex, front sloping, clypeus small, conical, not exposed; anterad broadly concave, angles rounded to canthus, latter completely dividing the eyes; eyes small, larger, however, than in tetrops; behind the eyes with an acuminate process, narrowing to base; above the eyes an oblong, deep cavity, extending to opposite the center of the acuminate process; above and behind the cavity, to base, strongly beset with large pits, which become nearly obsolete on the occiput. Mentum (fig. 2b) transverso-trapezoid, feebly lobed in front, with a central kidney-shaped excavation, finely granulate; strongly and distantly pitted toward margins, anterior and lateral pits bearing a seta, base nude. Mandibles symmetrical, porrect, regularly curved, laterad rounded, in distal half with an acute, upward and slightly inward directed tooth, and, on the inferior margin, in the basal third, another

${ }^{2}$ Bull. Soc. ent. France, p. 270, fig. ô, 1927. 
tooth; inner area between the teeth hollowed, base with an angular downward pointing lamina (larger than in tetrops). Antennæ typical to the genus (without a distinct clava), second to ultimate segment anterad progressively dilated, flattened, shining, setose. Prothorax transversal, front margin sinuate, antero-lateral angles acute, sides straight and narrowing to base, feebly dilated in posterior third, basal angles square and slightly produced, base emarginate with reflexed margin; laterad and basad strongly punctured; disc with an obsolete median line, and a distant, small group of punctures, in adjacent fields. Scutellum nearly twice as broad as long, rounded, with a few lateral, fairly large punctures, apex impunctate. Elytra with base produced and rounded, humeri angulate, gradually broadening to middle, thence semicircularly rounded to apex; surface irregular, suture glabrous, impunctate, shining, posterior declivate; punctured from the scutellum to margins, the puncturation much larger and denser in the humeral and lateral areas. Beneath black, strongly tinged with red (more so than in tetrops), especially the femora; abdomen black. Legs: anterior femur without the ridge-like tooth present in tetrops; all femora, on lower margin, fringed with long, dense, golden setæ; anterior tibiæ strongly bifurcate, with four equiform teeth; intermediate and posterior tibiæ with a spine in the distal half; anterior tibiæ with interior margin setose; intermediate and posterior tibiæ strongly setose on both margins; femora distantly punctured, with some punctures bearing prostrate, golden setæ (in tetrops glabrous); tarsi short and slender, each segment with a tuft of golden pile; claws small, simple. Female unknown.

Dimensions: Length (excl. mandib.) $25 \mathrm{~mm}$; mandibles $7 \mathrm{~mm}$. Head $13 \mathrm{~mm}$. wide; $6 \mathrm{~mm}$. long

Prothorax $11.5 \mathrm{~mm}$. wide; $5.75 \mathrm{~mm}$. long

Elytra $11.9 \mathrm{~mm}$. wide; $13.0 \mathrm{~mm}$. long

Holotype: $\hat{o}$, National Park, Queensland, McPherson Range, 3-4000 ft., Mar. 1932, Australia, Harvard Exp., Darlington; type no. 25,911. Paratopotype: $\hat{o}$, same data as the holotype, in the writer's collection.

Compared throughout with a specimen of $L$. tetrops Lea ${ }^{3}$ in

${ }^{3}$ Lea, Arthur M.: Trans. Proc. Royal Soc., South Australia, 40:272-436; 1916. 
the Angell collection, Academy of Natural Sciences, Philadelphia, bearing the late Lea's determination label; readily distinguished from the new species by the characters cited above, and the lack of hirsute adornment on the venter and appendages. As L. tetrops Lea has not been, to my knowledge, figured, I append a figure $(1,1 \mathrm{a}, 1 \mathrm{~b})$ of the insect here.

\section{Lissotes darlingtoni n. sp. 수 우}

Robust, ovate, piceous.

$$
\text { Figs. 3, 3a, ô ; 4, 4a, o }
$$

$\hat{o}$ Head transverso-quadrate, anterad nearly straight, anterolateral angles rounded, canthus and post-ocular process produced; clypeus broad, feebly trilobate; canthus emarginate and rounded, post-ocular process acuminate; eyes fairly small; mentum twice as broad as long, feebly lobed in front, laterad broadly rounded, sloping toward the center and front, strongly cribrate-punctate, more so on the sides. Front strongly declivate, subcarinate on vertex, beset with circular large pits (pockmarked), which become much larger and closer on the vertex and occiput. Mandibles porrect, arcuate, apices acute, finely remote punctulate, shining above, opaque beneath; outer margins rounded, with a median erect tooth; inner edge, in center, with a broad laminate process, which has on the left mandible two, on the right one, feeble indentation; between the central lamina and the base a circular excision, which, when mandibles are in repose, forms a top-like opening; base with an acute, diagonally forward pointing tooth and, above it, a deep excavation. Prothorax broad, anterior angles produced and nearly square, sides subparallel to posterior angles, latter diagonally truncate, base straight; nearly explanate on top, sides sloping, remotely punctured; disc with a central, ovate, strongly punctured depression and, laterad, right and left, two smaller ones; base, opposite the scutellum, with a triangular fovea. Scutellum small, broader than long, apex subacute, center with a transverse fovea. Elytra ovate, broadest beyond the middle, apex acutely rounded; humeri produced, mucronate; each elytron with two obsolete costæ, densely covered with large, ovate pits, becoming smaller and closer toward margin; margin reflexed with some punctures bearing short, golden setæ. Beneath, strongly punctured (excepting the abdomen), shining; 
abdominal segments straight, remotely punctured with shallow punctures. Anterior tibiæ distad broadly furcate, with three to four external teeth; intermediate and posterior tibiæ with a centrally located spine, those of the posteriors nearly obsolete.

$\&$ Analogous in sculpture to male, rufo-piceous, resembling closely $L$. novæe-zealandice $(\mathrm{Hp})$, differing from it, however, by its carinate and declivous head (novce-zealandice flattened), robust, narrower body (nova-zealandice broad and depressed), sculpture, etc. Dimensions of typical examples:

\begin{tabular}{|c|c|c|c|c|}
\hline & length; & width; & length; & width; \\
\hline Mandibl & $4.0 \mathrm{~mm}$. & & $1.25 \mathrm{~mm}$. & \\
\hline Hea & $3.75 \mathrm{~mm}$. & $7.5 \mathrm{~mm}$. & $2.0 \mathrm{~mm}$. & $4.5 \mathrm{~mm}$. \\
\hline rothorax & $4.8 \mathrm{~mm}$. & $8.0 \mathrm{~mm}$. & $4.5 \mathrm{~mm}$. & $6.75 \mathrm{~mm}$. \\
\hline Elytra & $9.5 \mathrm{~mm}$. & $7.5 \mathrm{~mm}$. & $9.0 \mathrm{~mm}$. & $6.75 \mathrm{~mm}$. \\
\hline
\end{tabular}

Holotype: $\hat{o}$, Mt. Donna Buang, Victoria, 1500-4000 ft., Dec. 7, 1931, Australia Harvard Exp., Darlington. In the Museum of Comparative Zoölogy, Cambridge, Mass.; type no. 25,912.

Paratopotypes: $3 \hat{o} \hat{o}$, same data as the holotype, in the collection of Museum of Comparative Zoology, Cambridge, Mass.; $4 \hat{o} \hat{o}$, same data as the preceding, in the writer's collection; one male is destined for the collection of the Australian National Museum. Allotype: $\circ$, same data as the holotype, in Museum of Comparative Zoölogy, Cambridge, Mass.

Paratopotype: + , same data as the allotype, in the writer's collection. Described from a series of eight males and two females, captured by Dr. P. J. Darlington, during the Harvard Expedition to Australia, in 1931-1932. I take great pleasure in naming this fine stag beetle after its discoverer.

Nigidius passaliformis $\mathrm{n}$. sp.

Fig. 5

Cylindrical, black, subopaque, glabrous; in habitus resembling a passalid.

o Head transverse, broader than long, anterior angles obtuse, diagonally bisinuate to opposite the eyes, latter large and entirely divided by the canthus, which is as wide as the eyes and 
laterad rounded; clypeus slightly produced and broadly angular; front strongly declivous, remotely punctured, with a feeble median ridge, and above the eyes an impunctate lateral crest, with adjacent oblong excavations; occipital area slightly elevated, with an adjoining median diamond-shaped depression. Antennæ typical to the genus, with no visible deviation. Mentum transverse-trapezoid, feebly bilobate (part of the left lobe broken off) in front, with two lateral ridges, and overlapping sculpture. Mandibles (apices broken off) minutely and densely punctulate, bent upward, curved, with a central inner tooth, latter distad with a horizontal depression, which thus forms two separate points, of which the superior is simple, and the inferior bicuspid. Prothorax quadrate, with a few obsolete scratches, anterior margin nearly straight, with antero-lateral angles produced and abruptly rounded; laterad nearly parallel to posterior angles, latter diagonal, base feebly sinuate; anterad strongly declivous, with a well-defined, median, truncate boss; disc with a central longitudinal fovea of irregular shape and, adjacent it on the left with two, and right three, smaller impressions. Scutellum: prescutellum cribrate-punctate, broad at base, narrowing toward the scutellum, which is heart-shaped, impunctate, with a basal three-pointed fovea. Elytra parallel, humerus mucronate, posterior regularly rounded; each elytron with 8 striæ, margin rugosely punctate; the striæ, which on first glance appear simple, under higher powers assume an entirely different character, i.e., consist of large circular punctures, interconnected by the sulca; first stria parallel to the suture, terminates on the declivity; second bends outward and forms a complete juncture with the sixth; third and fourth, joined; fifth encroaches on the connection between the second and sixth stria; seventh and eighth terminate near posterior margin; interspaces impunctate, broad and feebly convex, with the triangular area between the first and second stria strongly cibratepunctate. Beneath, prosternum and prosternal episternum strongly rugose-punctate; prosternal process rounded, not prominent; metasternal episternum punctate, with an impunctate, lateral ridge; metasternum with a median longitudinal impressed line, glabrous, anterad strongly confluently punctate; abdominal segments emarginate, base of each with a line of large punctures (apparently a stridulating apparatus); terminal segment remotely punctured. Anterior tibiæ strongly furcate, 
with five external teeth; intermediate and posterior tibiæ with distal spurs prominent, the outer spur longer than the inner one; intermediate tibiæ with two, posterior with three external spines. Female unknown, but as characteristic to the genus, may resemble the male very closely in habitus, with slightly modified mandibles. Dimensions; Length (excl. mandib.) 18.5 mm.; mandibles (minus apices) $1.75 \mathrm{~mm}$.

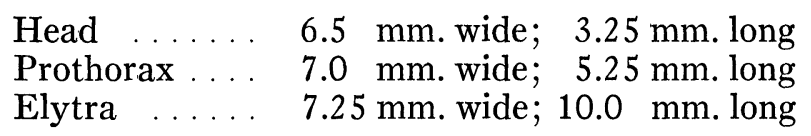

Holotype: $\delta$, West Africa, Coll. Harvard, in the Museum of Comparative Zoölogy, Cambridge, Mass.; type No. 25,913.

Superficially resembling the Australian Figulus trilobus Westw., ${ }^{4}$ assigned, subsequently, by Parry ${ }^{5}$ to Nigidius; it differs, however, from $F$. trilobus by the broader head (in trilobus more triangular in outline), mandibles, cylindrical body (trilobus depressed), scutellum (trilobus wedge-shaped), etc.; it can be mentioned here that $F$. trilobus Westw. is a true Figulus, and not a Nigidius, as Parry suggested.

Ceratognathus tasmanus n. sp. $\hat{o} q$

Figs. 6, 6a $\hat{o}, 7$ 우

Oblong, convex, rufous, cribrate-punctate, pubescent; pubescence on the dorsum intermixed (in both sexes) with lanceolate yellowish-gray squamæ.

ô Head transversal, three times as broad as long $(3: 1)$, strongly sloping toward the front, anterior angles rounded, behind the eyes broader; vertex with two tubercles on line with the center of the prominent eyes. Antennæ slender; scape onethird the length of the entire antenna, second segment globular, third to seventh uniformly dilated to apex, eighth, ninth and the tenth lobate; clava one-fifth longer than the funicle, pale rufous, with grayish pubescence. Mandibles regularly curved from base to tip, bent upward from the basal third, apices of both mandibles bicuspid, strongly punctate; at the middle of

4 Westwood, J. C.: Ent. Mag. 5: 263, 1838.

${ }^{5}$ Parry, F. J. S.: Trans. Ent. Soc. London, p. 343, 1873. 
the exterior margin a lateral, laminate, obtuse tooth and, anterad, near the apical third, a superior, subacute tooth. Prothorax one and one half times broader than long, front margin gently bisinuate, anterior angles rounded, diverging diagonally to the middle, thence nearly parallel to posterior angles, latter broadly rounded, base nearly straight; disc with an oblong median depression and, postero-laterad, circular impression. Scutellum broad, apex rounded, base impunctate, with an irregular impressed line, which circumscribes, in the apical area, five unequal punctures. Elytra with humeral angles broadly rounded, sides parallel, apex regularly rounded, suture with an ill-defined costa and each elytron with two irregular costæ, terminating on the posterior declivity. Beneath, densely clothed with long grayish pubescence; abdominal segments nearly explanate, feebly emarginate, confluently punctate; posterior segment slightly convex. Intermediate and posterior tibiæ serrate, with a prominent spine near the apical third; spurs well developed; tarsi short and fairly stout, ultimate segment nearly as long as the others combined.

$q$ Of the same general appearance as the male, but with head smaller $(2: 1)$, with frontal margin slightly transversocarinate, mandibles shorter than the head, with a central bicuspid tooth on the inferior edge, thorax narrower in front and longer than wide, stouter legs, less prominent spines, etc.

Dimensions: of $12.5 \mathrm{~mm}$. long, mand. incl.; width, $4.5 \mathrm{~mm}$. \& $13.75 \mathrm{~mm}$. long, mand. incl.; width, $5.6 \mathrm{~mm}$.

Holotype: $\hat{o}$, Tasmania, Edwards Collections, in the American Museum of Natural History, New York, N. Y.

Allotype: $\&$, same data as the holotype, in the American Museum of Natural History, New York, N. Y.

Allied to Ceratognathus bitumulatus Carter, from which it can be readily distinguished by the shape of the mandibles, squamæ, non-tumulate elytra, etc. The female here figured has asymmetrical margins on the pronotum; left margin has a slight protuberance, which is missing on the opposite side, as indicated by the broken line in the drawing. Described from a pair of (rather dilapidated) examples; the male is minus left antenna, anterior tibiæ, right intermediate leg and all tarsi; the 
female lacks the right antenna, left intermediate leg and posterior tarsus and the tarsi of right anterior and intermediate legs.

\section{Explanation of Plate IV}

FIG. 1. Lissapterus tetrops Lea, ô. 1A. Lateral aspect of head. 1B. Mentum.

Frg. 2. Lissapterus montivagus n. sp., ô. 2A. Lateral aspect of head. $2 \mathrm{~B}$. Mentum.

FIG. 3. Lissotes darlingtoni n. sp., $\hat{o}$. 3A. Lateral aspect of head.

Fig. 4. Lissotes darlingtoni n. sp., $\$$. 4A. Lateral aspect of head. 4B. Mentum. FIG. 5. Nigidius passaliformis n. sp., $\hat{\sigma}$.

FIG. 6. Ceratognathus tasmanus n. sp., ô. 6A. Lateral aspect of the mandibles. Fic. 7. Ceratognathus tasmanus n. sp., $ᄋ$. 7A. Right anterior tibia. 

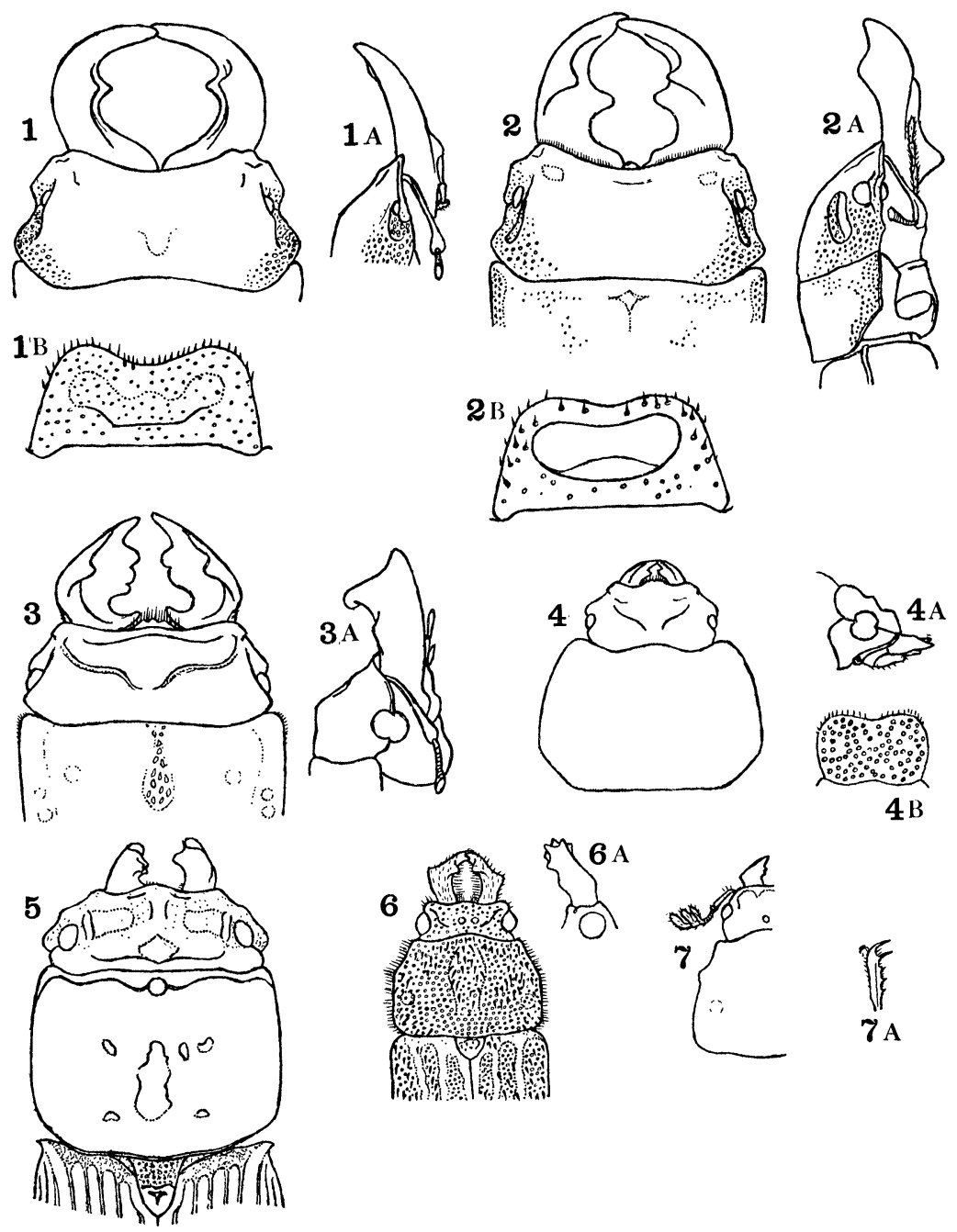

Benesh - Exotic Stag Beetles 

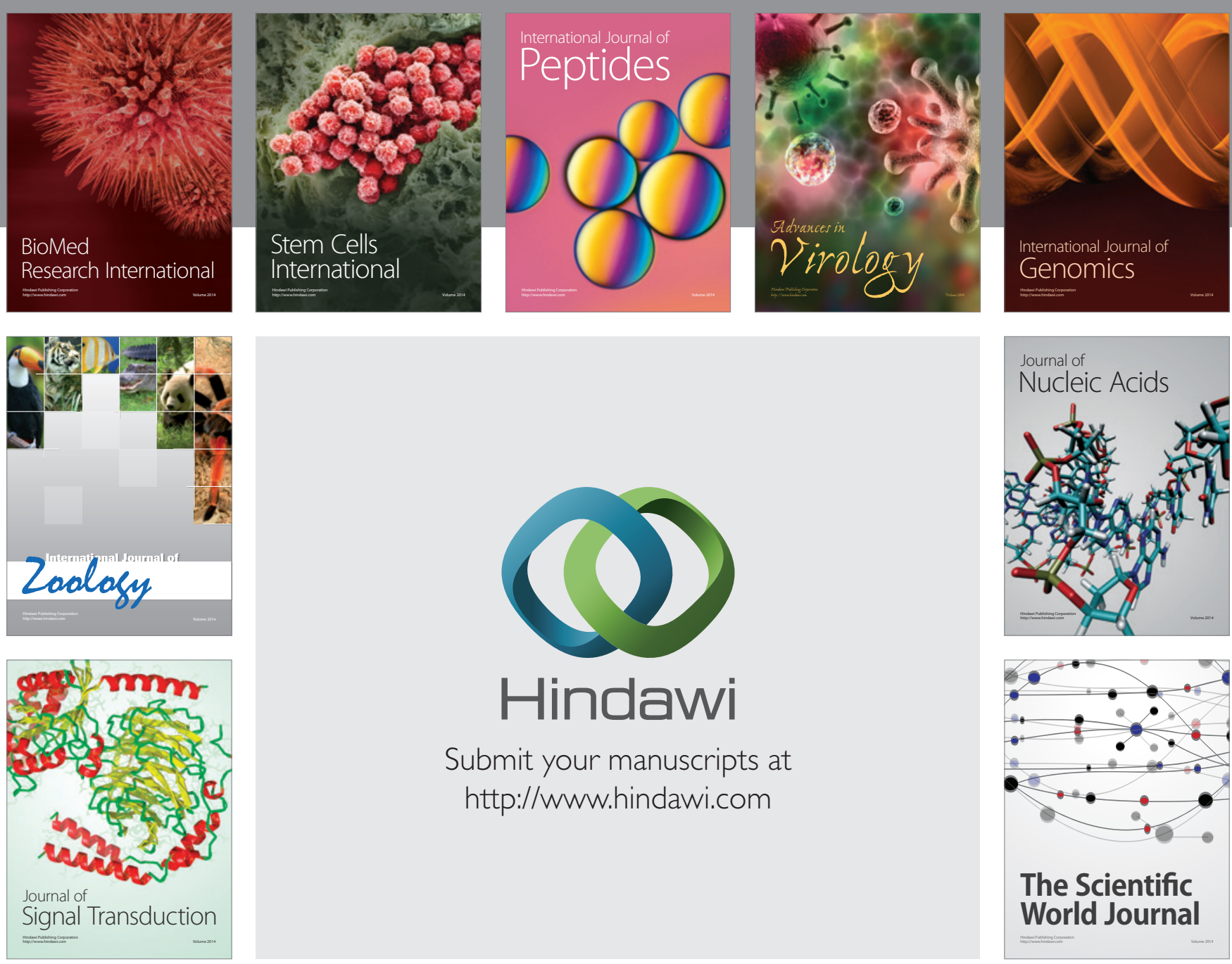

Submit your manuscripts at

http://www.hindawi.com
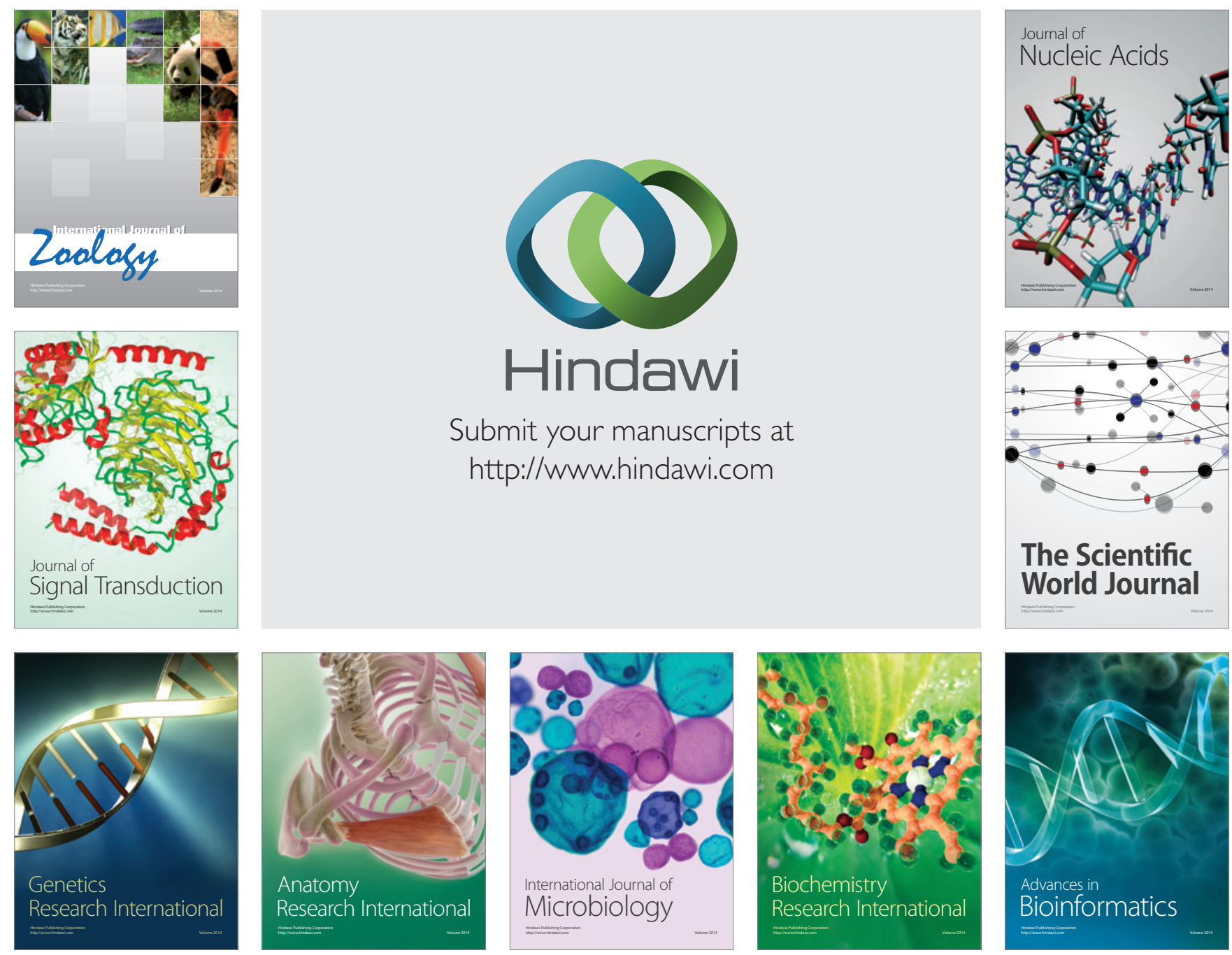

The Scientific World Journal
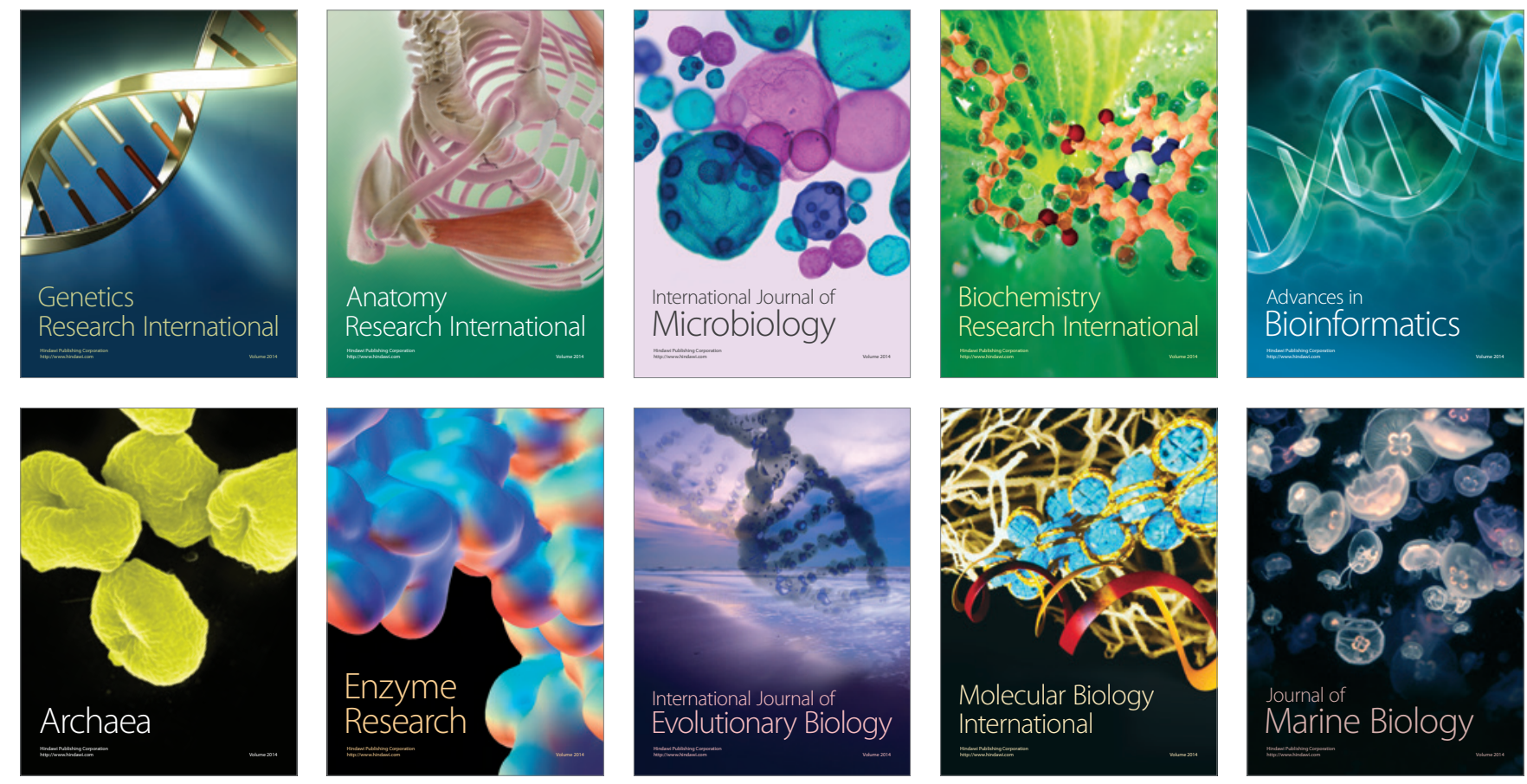